\title{
Analisis Kadar Akrilamida Dalam Sediaan Roti Kering Secara KCKT
}

\author{
Sandra Hermanto ${ }^{1 *}$, Robiatul Adawiyah ${ }^{2}$ \\ ${ }^{1}$ Program Studi Kimia Fakultas Sains dan Teknologi UIN Syarif Hidayatullah Jakarta \\ ${ }^{2}$ Program Studi Farmasi Fakultas Sains dan Teknologi UIN Syarif Hidayatullah Jakarta \\ Jl. Ir. H. Juanda No. 95 Ciputat Jakarta 15142 \\ email : sandra.hermanto@gmail.com
}

\begin{abstract}
Abstrak
Akrilamida merupakan zat yang berbahaya dan berpotensi menyebabkan kanker pada sekitar $2 \%$ kasus tiap tahun di dunia. Akrilamida biasanya ditemukan pada makanan yang diproses menggunakan suhu tinggi (di atas $150^{\circ} \mathrm{C}$ ), misalnya pada roti kering. Penetapan kandungan akrilamida dalam sediaan roti kering yang beredar di wilayah Jakarta Timur telah dilakukan dengan menggunakan Kromatografi Cair Kinerja Tinggi (KCKT). Preparasi sampel dilakukan dengan teknik ekstraksi menggunakan pelarut diklorometan dan etanol (1:15). Pengukuran kadar akrilamida dilakukan dengan kolom C18 (reverse phase) dengan detektor UV-Vis pada panjang gelombang $210 \mathrm{~nm}$ dengan fase gerak asam fosfat $85 \%$ dalam asetonitril:air (5:95), laju alir $0.5 \mathrm{ml} / \mathrm{menit}$. Hasil analisis menunjukkan waktu retensi yang dibutuhkan untuk mengelusi akrilamida adalah 7.1 menit, dengan koefisien variasi $0.67 \%$ dan presisi sebesar $0,38 \%, 0,74 \%$ dan $0,21 \%$ serta uji perolehan kembali 98,18\%. Pembuatan kurva kalibrasi pada rentang konsentrasi $0,1-1,6 \mu \mathrm{g} / \mathrm{ml}$ menghasilkan koefisien linieritas 0.999982 dan batas deteksi $0.0126 \mu \mathrm{g} / \mathrm{ml}$ serta batas kuantitasi $0.0420 \mu \mathrm{g} / \mathrm{ml}$. Kadar akrilamida untuk ketiga sampel produk roti kering yaitu $0.0541 \pm 0.0270$ (sampel 1); 0.0851 \pm 0.0629 (sampel 2); and $0.3445 \pm 0.2539 \mu \mathrm{g} / \mathrm{g}$ (sampel 3). Kadar akrilamida pada masing-masing sampel masih berada di bawah ambang batas standar yang dikeluarkan FDA.
\end{abstract}

Kata kunci: Akrilamida; Roti Kering; Kromatografi Cari Kenerja Tinggi

\begin{abstract}
Acrylamide is classiffied as a hazardous material which has potency as human's body carcinogenic for the case of cancer about $2 \%$ per year in the world. Acrylamide was usually found in food processed by the high temperature (above $150^{\circ} \mathrm{C}$ ) such as crisp bread. Determination of acrylamide in crisp bread which obtained from East Jakarta region had been done by using High Performance Liquid Chromatograpy (HPLC). Sample was extracted with mix of dichlorometane and ethanol (1:15) as solvent. HPLC analysis performed by using C18 colomn with UV-Vis detector at the wavelength $210 \mathrm{~nm}$, with phosphoric acid 85\%(v/v) as a solvent in a composition of acetonitrilewater (5:95), in flow rate of eluent $0.5 \mathrm{ml} /$ minute. The result showed that acrylamide was eluted in retention time 7.1 minutes which coefficient of variant $0.67 \%$, precision number $0,38 \%, 0,74 \%$, $0,21 \%$ and percent of recovery $98,18 \%$. Calibration curve performed in the range of $0.1-1.6 \mu \mathrm{g} / \mathrm{ml}$ yielding correlation coefficient 0.999982 , and limit of detection $0.0126 \mu \mathrm{g} / \mathrm{ml}$; as well as limit of quantitation $0.0420 \mu \mathrm{g} / \mathrm{ml}$. Acrylamide concentrations in three crisp breads were $0.0541 \pm 0.0270$ (sample 1); $0.0851 \pm 0.0629$ (sample 2); and $0.3445 \pm 0.2539 \mu \mathrm{g} / \mathrm{g}$ (sample 3). The result of acrylamide concentrations still lower than standard fixed of FDA.
\end{abstract}

Keyword: Acrylamide; Crisp Bread; High performance Liquid Chromatography 


\section{PENDAHULUAN}

Akrilamida adalah suatu senyawa kimia yang secara alamiah terdapat dalam produk makanan dan bukan merupakan zat aditif yang sengaja ditambahkan dalam produk makanan. Senyawa ini terbentuk karena proses pengolahan tertentu misalnya dengan adanya pemanasan pada suhu tinggi (Harahap, 2006). Akrilamida sering digunakan dalam penjernihan air minum atau untuk analisa biomolekul di laboratorium. Sejak tahun 1950, akrilamida diproduksi dengan cara hidrasi akrilonitril dalam bentuk monomer sedang poliakrilamida ada dalam bentuk polimer dengan rumus kimia $\left(\mathrm{CH}_{2} \mathrm{CHCONH}_{2}\right)$.

Akrilamida merupakan senyawa kimia berwarna putih, tidak berbau, berbentuk kristal padat yang sangat mudah larut dalam air dan mudah bereaksi melalui reaksi amida atau ikatan rangkapnya. Monomernya cepat berpolimerisasi pada titik leburnya atau di bawah sinar ultraviolet. Akrilamida dalam larutan bersifat stabil pada suhu kamar dan tidak berpolimerisasi secara spontan (FDA, 2004).

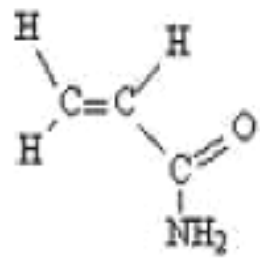

Gambar 1. Struktur kimia akrilamida (Otles, 2004)

$\begin{array}{crr}\text { Akrilamida merupakan } & \text { senyawa } \\ \text { intermediat yang dicurigai bersifat }\end{array}$ karsinogenik pada manusia. Dalam bentuk murni, akliramida memiliki berat molekul 71,09 , titik didih dan titik leleh masing-masing 125 dan 87,5 Celcius. Akrilamida merupakan faktor yang menyebabkan penyakit kanker pada sekitar 2\% (100-700 dari 45.000) kasus tiap tahun di dunia, dimana bentuk monomernya bersifat racun terhadap system saraf pusat, sedangkan bentuk polimer diketahui tidak bersifat toksik (WHO, 2002).

Akrilamida digunakan secara umum pada pembuatan poliakrilamida. Poliakrilamida komersial mengandung 0,05$5,0 \%$ akrilamida (bergantung pada jumlah penggunaan poliakrilamida tersebut) dan sekitar $1 \mathrm{mg} / \mathrm{kg}$ residu monomer akrilonitril. Keberadaan akrilamida di dalam air minum sudah banyak diteliti. Namun, sedikit sekali penelitian yang mengungkapkan bahayanya di dalam makanan sehari-hari (Harahap, 2006).

Hasil penelitian sejumlah pakar teknologi pangan dari Universitas Stockholm Swedia menyebutkan beberapa jenis pangan olahan yang disukai masyarakat justru mengandung senyawa yang bisa menyebabkan kanker (karsinogen) dalam kadar tinggi (Swedish National Food Authority (SNFA). World Health Organization (WHO) menyebutkan pengolahan makanan berbahan dasar pati (seperti kentang, singkong, beras dan gandum) pada suhu yang sangat tinggi (di atas $120^{\circ} \mathrm{C}$ ), baik melalui pemanggangan atau penggorengan dapat menyebabkan terbentuknya senyawa akrilamida. Hasil temuan ini merupakan lembaran baru dalam penelitian di bidang pangan, terlebih mengenai keberadaan akrilamida dalam makanan (WHO, 2002).

Hasil uji toksisitas terhadap hewan percobaan menunjukkan akrilamida terbukti bersifat karsinogenik. Gangguan kesehatan yang disebabkan akrilamida terjadi karena dampak genotoksik terutama pada jaringan sel syaraf dan pembuluh darah. Akrilamida dicurigai lebih bersifat neurotoksik dibandingkan dengan glisidamida. Pada ginjal, hati dan sistem reproduksi juga terjadi akumulasi. Berdasarkan percobaan pada hewan, akrilamida diekskresikan dalam jumlah besar melalui urin dan empedu sebagai metabolitnya (FDA, 2004; Yahdiana, 2006).

World Health Organization (WHO) menyatakan bahwa pada populasi umum, ratarata asupan akrilamida melalui makanan berada pada rentang $0,3-0,8 \mu \mathrm{g} / \mathrm{kg} \mathrm{BB} / \mathrm{hari}$. Environmental Protection Agency (EPA) pada tahun 1992 dan WHO pada tahun 1985 telah membatasi kadar akrilamida dalam air minum sebesar 0,5 $\mu \mathrm{g} / \mathrm{liter}$ (ppb) (WHO, 2002). Office of Environmental Health Hazard Assesment (OEAHHA), salah satu divisi EPA yang berlokasi di California, Amerika Serikat telah menetapkan bahwa 0,2 $\mu \mathrm{g} / \mathrm{hari}$ akrilamida tidak bersifat sebagai agen pencetus kanker.

Sebaliknya hasil penelitian Badan Pengawas Makanan Swedia menyebutkan bahwa konsentrasi akrilamida yang sangat besar ditemukan pada makanan yang digoreng (keripik kentang $1200 \mu \mathrm{g} / \mathrm{kg}$; kentang goreng, $450 \mu \mathrm{g} / \mathrm{kg}$ ), dan makanan yang dipanggang (sereal dan roti, 100-200 $\mu \mathrm{g} / \mathrm{kg}$ ) (OEAHHA, 
2005; Simanjuntak, 2006). Akrilamida terbentuk dari reaksi pada suhu tinggi antara karbohidrat, protein, asam amino, serta komponen-komponen lain yang berada dalam jumlah kecil. Mekanisme pembentukan akrilamida antara lain:

a. Terbentuk dari dekarboksilasi atau dehidrasi bebarapa asam organik tertentu yang meliputi asam malat dan asam laktat.

b. Terbentuk dari akrolein atau asam akrilat hasil degradasi karbohidrat, lemak, atau asam amino bebas seperti asparagin, alanin, metionin, dan glutamin yang memiliki struktur mirip akrilamida.

c. Terbentuk langsung dari asam amino asparagin yang merupakan asam amino dengan struktur mirip dengan akrilamida dan diduga senyawa tersebut yang paling berperan dalam pembentukan akrilamida, karena dapat bereaksi dengan gula pada suhu tinggi.

Mekanisme pembentukan akrilamida lainnya diduga berhubungan dengan reaksi Maillard yang ditemukan pada tahun 1912 oleh Louis Carnille Maillard. Akrilamida dianggap sebagai produk samping dari reaksi Maillard yang terjadi antara asam amino dengan gula pereduksi (glukosa, fruktosa, ribosa, dan lainlain) atau sumber karbonil lainnya (WHO, 2002).

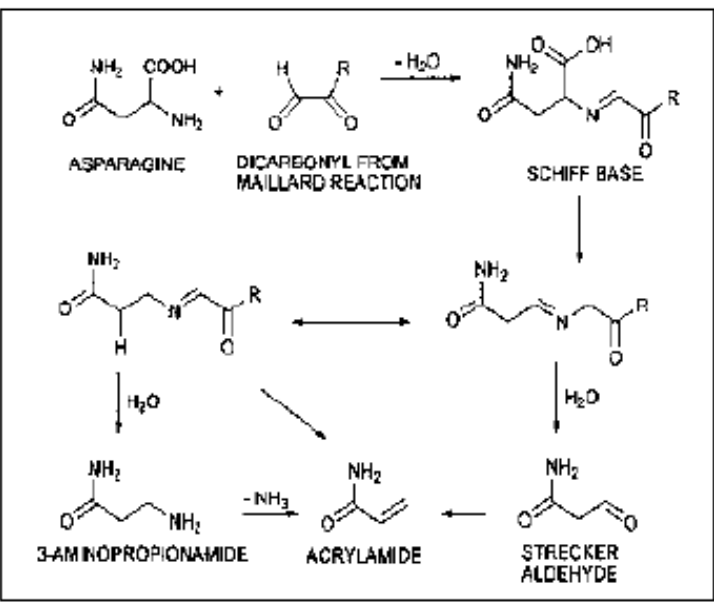

Gambar 2. Pembentukan akrilamida melalui Reaksi Mailard (WHO, 2002).

Dalam rangka meningkatkan kualitas kesehatan masyarakat, metode analisis kimia memiliki peran yang amat penting dalam memberikan informasi tentang keamanan suatu produk pangan. Berbagai metode analisis yang telah dikembangkan untuk penetapan akrilamida antara lain kromatografi gasspektrofotometri massa dan kromatografi cair kinerja tinggi (Lubomir Karasek, 2008).

Pengujian kadar akrilamida dengan metode Kromatografi Cair Kinerja tinggi (KCKT) dalam berbagai sediaan roti kering telah dilakukan dimana analisis dilakukan menggunakan kolom Supelcosil C-18 dengan detektor UV-Vis pada panjang gelombang 210 $\mathrm{nm}$, fase gerak asam fosfat dalam asetonitrilair dengan perbandingan 5:95, laju alir 0,5 $\mathrm{ml} /$ menit dan pelarut yang digunakan adalah asetonitril dan air. Selanjutnya untuk menjamin validitas data hasil analisa dilakukan pengukuran dengan menggunakan standar akrilamida (Sigma Aldrich) dan menetapkan parameter-parameter validasi (presisi, akurasi, limit deteksi dan limit kuantisasi).

\section{METODE PENELITIAN}

\section{Bahan dan Alat}

Standar akrilamida pro analisa (Sigma Aldrich), Aquabidest, Asam fosfat (pa), Asetonitril and methanol terstandar untuk analisa kromatografi; Diklorometan (pa) dan etanol (pa) untuk mengekstrak akrilamid dari matriks sampel.

Alat-alat yang digunakan adalah HPLC (Perkin Elmer series 200 Autosampler) untuk pengujian kadar akrilamid dengan kolom supelcosil C-18 $(0,5 \mathrm{~cm} \times 25 \mathrm{~cm})$, detektor uv dan fase gerak asetonitril:air (5:95), filter fase gerak dan millipore, penangas air, shaker incubator, $\mathrm{pHmeter}$ untuk mengatur $\mathrm{pH}$ fase gerak, peralatan ekstraksi dan sentrifugasi (Sorvall RC5c Plus) untuk memisahkan pelarut dengan pengotor.

\section{Sampel}

Sampel yang diteliti terdiri dari tiga produk roti kering dalam kemasan yang berasal dari pasar swalayan di Jakarta Timur DKI Jakarta dengan merk dan nomor registrasi berbeda. Kategori sampling berdasarkan kode kadaluarsa dan kode produksinya.

\section{Preparasi Sampel}

a. Pembuatan larutan standar akrilamida

25,0 mg standar akrilamida ditimbang dan dimasukkan kedalam labu ukur 50,0 mL, 
dilarutkan dengan fase gerak (asetonitril:air) sampai tanda batas, dikocok hingga homogen (larutan A). 1,0 mL larutan A dipipet, dan dimasukkan kedalam labu ukur 50,0 mL kemudian ditambahkan dengan fase gerak yang digunakan sampai tanda batas (larutan B). Dari larutan B dibuat larutan akrilamida dengan konsentrasi 0,$1 ; 0,2 ; 0,4 ; 0,8$ dan 1,6 $\mu \mathrm{g} / \mathrm{mL}$.

\section{Pembuatan fase gerak}

$50 \mathrm{~mL}$ asetonitril dan $950 \mathrm{~mL}$ aquabidest dimasukkan kedalam labu ukur $1000 \mathrm{~mL}$. Kemudian 0,2 mL asam fosfat $85 \%$ ditambahkan, dikocok hingga homogen, lalu disaring dengan filter eluen, selanjutnya dihilangkan udara dalam fase gerak dengan pengaduk ultrasonik.

\section{Validasi metode (OSW EPA Method, 316)}

Kondisi optimum analisa ditentukan berdasarkan hasil uji kesesuian sistem, dengan parameter sebagai berikut:

\begin{tabular}{|l|l|}
\hline Spesifikasi kolom & Supercolsil C18 \\
\hline Detektor & UV \\
\hline Panjang gelombang & $210 \mathrm{~nm}$ \\
\hline Fase gerak & Asetonitril:air (5:95) \\
\hline Laju alir & $0.5 \mathrm{~mL} / \mathrm{menit}$ \\
\hline Volume injeksi & $10 \mu \mathrm{L}$ \\
\hline Mode elusi & Isokratik \\
\hline
\end{tabular}

Tahapan validasi metode meliputi :

a. Pembutan kurva kalibrasi dengan larutan standar akrilamida 0,$1 ; 0,2 ; 0,4 ; 0,8$ dan 1,6 $\mu \mathrm{g} / \mathrm{mL}$.

b. Pengujian batas deteksi dan batas kuantitasi. Batas deteksi dan batas kuantitasi dihitung secara statistik melalui persamaan regresi linier dari kurva kalibrasi yang dihasilkan.

c. Uji keterulangan (presisi). Larutan standar 0,$1 ; \quad 0,2 ;$ dan $0,4 \mu \mathrm{g} / \mathrm{mL}$ disuntikkan sebanyak $10 \mu \mathrm{L}$ kedalam kolom terpilih, diulang sebanyak 5 kali, kemudian dicatat luas puncaknya dan dihitung koefisien variasinya.

d. Uji perolehan kembali (akurasi)

$20 \mathrm{mg}$ standar akrilamida ditimbang, dan ditambahkan sampel roti kering 15 gram. Kemudian dilarutkan dalam $45 \mathrm{~mL}$ diklormetan dan ditambahkan $3 \mathrm{~mL}$ etanol, dikocok dengan shaker incubator pada kecepatan $250 \mathrm{rpm}$ selama 60 menit. Lalu sampel dicuci dengan diklormetan $3 \mathrm{~mL}$ sebanyak 2 kali pencucian dan disaring, kemudian filtrat ditambahkan $20 \mathrm{~mL}$ fase gerak yang digunakan. Diklormeten dan etanol diuapkan diatas penangas air pada temperature $70^{\circ} \mathrm{C}$. Lalu disetrifugase dengan kecepatan $16000 \mathrm{rpm}$ selama 15 menit. Larutan sampel disaring dengan kertas saring whatman. $10 \mu \mathrm{L}$ analit disuntikkan kedalam kolom HPLC. Perlakuan yang sama dilakukan terhadap sampel tanpa akrilamida. Persen perolehan kembali ditentukan berdasarkan metode standar adisi.

\section{Penetapan kadar akrilamida dalam produk roti kering}

Sampel roti kering yang sudah dihaluskan ditimbang sebanyak 15 gram kemudian dilarutkan dalam $45 \mathrm{~mL}$ diklormetan dan ditambahkan $3 \mathrm{~mL}$ etanol, dikocok dengan incubator shaker pada kecepatan $250 \mathrm{rpm}$ selama 60 menit. Larutan sampel dicuci dengan diklormetan $3 \mathrm{~mL}$ sebanyak 2 kali pencucian dan disaring, ke dalam filtrat ditambahkan $20 \mathrm{~mL}$ fase gerak yang digunakan. Diklormetan dan etanol diuapkan diatas penangas air pada temperature $70^{\circ} \mathrm{C}$. Lalu disetrifugase dengan kecepatan 16000 rpm selama 15 menit. Sampel disuntikkan sebanyak $10 \mu \mathrm{L}$ kedalam kolom HPLC, kemudian dicatat luas puncaknya. Percobaan diulang sebanyak 2 kali. Kadar akrilamida dihitung dengan menggunakan persamaan regresi yang diperoleh dari kurva kalibrasi.

\section{HASIL DAN PEMBAHASAN}

\section{Uji Kesesuaian Sistem (OSW EPA Method, 8316)}

Uji kesesuaian sistem dilakukan dengan 5 kali pengulangan pada kondisi yang telah ditentukan, sampai diperoleh nilai dengan persyaratan tertentu pada parameter masingmasing. Hasil uji kesesuaian sistem terdapat pada tabel 1 .

Tabel 1. Hasil Uji Kesesuaian Sistem

\begin{tabular}{|c|c|c|c|c|c|}
\hline $\begin{array}{c}\text { Komposisi } \\
\text { fase gerak }\end{array}$ & $\begin{array}{c}\text { Jml pelat } \\
\text { teoritis }\end{array}$ & HETP & $\begin{array}{c}\text { Faktor } \\
\text { selektifitas }\end{array}$ & $\begin{array}{c}\text { Faktor } \\
\text { kapasitas }\end{array}$ & $\begin{array}{c}\text { Resolu } \\
\text { si (R) }\end{array}$ \\
\hline $\begin{array}{c}\text { Asetonitril- } \\
\text { air (5:95) }\end{array}$ & 3253 & 0.0077 & 1.75 & 0.49 & 1.32 \\
\hline
\end{tabular}


Berdasarkan hasil validasi metode sebanyak 5 kali pengulangan, menunjukkan semua parameter memenuhi persyaratan uji dimana untuk nilai jumlah plat teoritis $(\mathrm{N})$ $>2500$, nilai HETP $<$ N. Faktor selektifitas 1,75 menit; faktor kapasitas 0,6 menit; resolusi (R) 1,32. Hal tersebut menunjukkan sistem instrumental yang digunakan cukup memenuhi kesesuaian dan keefektifan kondisi operasional.

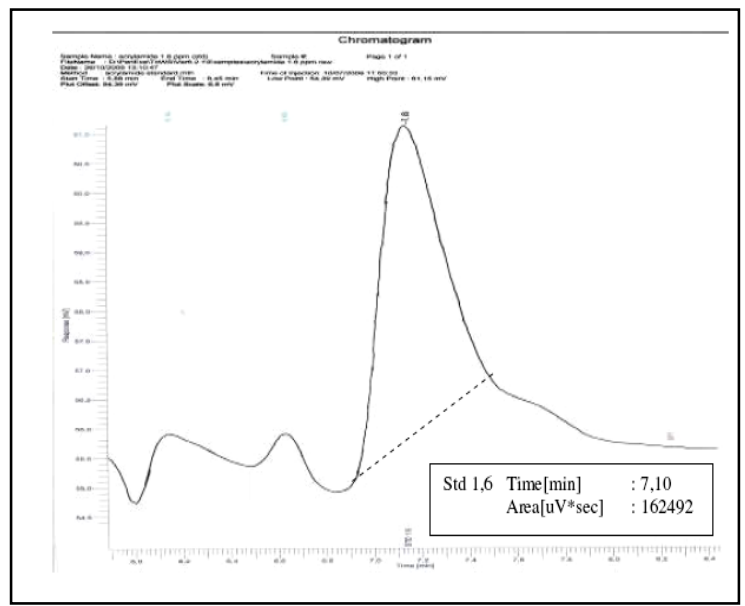

Gambar 3. Kromatogram standar akrilamida 1,6 $\mu \mathrm{g} / \mathrm{mL}$ (Fase gerak asetonitril-air (5:95); kolom Supelcosil C18; volume injeksi $10 \mu \mathrm{L}$; laju alir $0,5 \mathrm{~mL} / \mathrm{menit}$; panjang gelombang $210 \mathrm{~nm}$.

\section{Uji Linieritas}

Hasil uji linieritas dengan menggunakan standar akrilamida 0,$1 ; 0,2 ; 0,4 ; 0,8$ dan 1,6 $\mu \mathrm{g} / \mathrm{mL}$ menghasilkan data sebagai berikut :

Tabel 2. Hasil uji linearitas

\begin{tabular}{|c|c|}
\hline Konsentrasi $(\boldsymbol{\mu g} / \mathrm{mL})$ & Area \\
\hline 0,1 & 10809 \\
\hline 0,2 & 20107 \\
\hline 0,4 & 40389 \\
\hline 0,8 & 80991 \\
\hline 1,6 & 162492 \\
\hline
\end{tabular}

Selanjutnya data tersebut dipetakan ke dalam kurva kalibrasi sehingga diperoleh persamaan regresi linier sebagaimana terlihat pada gambar 3 .

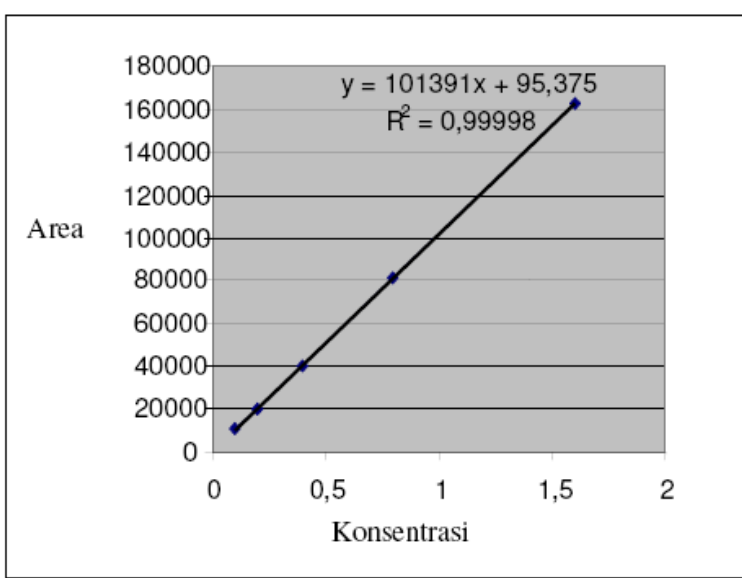

Gambar 3. Kurva Kalibrasi larutan standar akrilamida (Fase gerak asetonitril-air (5:95); kolom Supelcosil C18; volume injeksi $10 \mu \mathrm{L}$; laju alir $0,5 \mathrm{~mL} / \mathrm{menit}$; panjang gelombang $210 \mathrm{~nm}$.

\section{LOD, LOQ, Koefisien variasi \&Presisi}

Dari persamaan regresi yang diperoleh berdasarkan kurva kalibrasi, selanjutnya ditentukan LOD dan LOQ yang menghasilkan nilai batas deteksi sebesar $0.0126 \mu \mathrm{g} / \mathrm{mL}$; dan batas kuantitasi $0.0420 \mu \mathrm{g} / \mathrm{ml}$. Koefisien variasi diturunkan dari fungsi $\left(\mathrm{V}_{\mathrm{xo}}\right)$ sebesar $0.6700 \%$ (<5\%). Data diatas diperoleh untuk mengetahui konsentrasi analit terendah yang dapat terdeteksi dan kuantitatas senyawa yang terdapat dalam konsentrsai rendah.

Tabel 3. Hasil uji presisi

\begin{tabular}{|c|c|c|c|}
\hline $\begin{array}{c}\text { Konsentrasi } \\
(\mu \mathrm{g} / \mathrm{mL})\end{array}$ & Area & Area rata - rata & RSD (\%) \\
\hline \multirow{5}{*}{0,1000} & 10825 & \multirow{5}{*}{10840} & \multirow{5}{*}{0,38} \\
\hline & 10889 & & \\
\hline & 10809 & & \\
\hline & 10798 & & \\
\hline & 10879 & & \\
\hline \multirow{5}{*}{0,2000} & 20407 & \multirow{5}{*}{20368} & \multirow{5}{*}{0,74} \\
\hline & 20500 & & \\
\hline & 20107 & & \\
\hline & 20425 & & \\
\hline & 20395 & & \\
\hline \multirow{5}{*}{0,4000} & 40344 & \multirow{5}{*}{40298} & \multirow{5}{*}{0,21} \\
\hline & 40158 & & \\
\hline & 40295 & & \\
\hline & 40389 & & \\
\hline & 40304 & & \\
\hline
\end{tabular}

Selanjutnya berdasarkan hasil penyuntikan Larutan standar akrilamida dengan konsentrasi yang sama sebanyak lima kali penyuntikan dari 3 konsentrasi yang 
berbeda, yaitu $0.1 ; 0.2 ;$ dan $0.4 \mu \mathrm{g} / \mathrm{mL}$ diperoleh nilai RSD sebesar $0,38 \% \quad(0,1$ $\mu \mathrm{g} / \mathrm{mL}) ; 0,74 \%(0,2 \mu \mathrm{g} / \mathrm{mL})$ dan $0,21 \%(0,4$ $\mu \mathrm{g} / \mathrm{mL}$ ) sebagaimana terlihat pada tabel 3 . Hasil ini menunjukkan bahwa uji presisi masing-masing masih berada di bawah rentang $2 \%$. Hal ini mengindikasikan bahwa metode ini cukup presisi dalam mengukur kadar akrilamida bahkan untuk konsentrasi yang relatif rendah (Edi Y, 2009).

\section{Persen recovery}

Dalam penentuan nilai uji perolehan kembali digunakan metode penambahan baku (standar adisi) dimana sampel yang diduga mengandung akrilamida ditambahkan standar baku akrilamida yang telah diketahui kadarnya. Metode penambahan baku dipilih untuk meningkatkan sensitifitas pengukuran matriks sampel yang memiliki kandungan akrilamid dengan jumlah yang relatif rendah.

Kondisi ekstraksi awal yang digunakan berdasarkan penelitian sebelumnya yaitu sampel diekstraksi dengan menggunakan etanol dan diklorometana (1:20) (Ajeng, 2007). Namun demikian dalam penelitian ini dilakukan modifikasi perbandingan etanol dan diklorometan menjadi (1:15) untuk memperoleh kromatogram yang bagus, walaupun hasilnya menunjukkan tidak ada perbedaan yang signifikan.

Pengadukan dengan shaker inkubator dilakukan agar analit dapat larut dengan pelarut sehingga terpisah dari pengotor. Larutan hasil pengocokan dicuci dengan $3 \mathrm{~mL}$ diklormetana sebanyak 2 kali pencucian dan disaring, kemudian ditambahkan $20 \mathrm{~mL}$ fase gerak yang digunakan. Pencucian ini bertujuan untuk mengikat sisa-sisa analit dari pelarut. Sentrifugasi dengan kecepatan $16000 \mathrm{rpm}$ selama 15 menit bertujuan untuk memisahkan analit dengan pelarut sehingga akan mempermudah pada saat proses penyaringan. Penyaringan dengan kertas saring Whatman No. 2 dilakukan untuk meminimalkan kontaminasi dari zat-zat pengotor, karena adanya pengotor yang masih tersisa dalam pelarut dapat mengganggu hasil analisa. Penguapan pelarut dilakukan pada suhu $70^{\circ} \mathrm{C}$, diatas titik didih diklorometana dan dibawah titik didih air, sehingga diharapkan diklorometana dapat menguap seluruhnya.
Hasil ekstraksi dengan menggunakan diklorometan menghasilkan persen perolehan kembali sebesar 99,18\% untuk konsentrasi akrilamida $0,5193 \mu \mathrm{g} / \mathrm{mL} \quad$ (Tabel 4). Berdasarkan hasil persen perolehan kembali tersebut metode ekstraksi di atas telah memenuhi standar validasi yang dipersyaratkan sehingga dapat digunakan untuk penetapan kadar sampel.

Tabel 4. Hasil uji perolehan kembali

\begin{tabular}{|c|c|c|c|c|c|c|c|}
\hline $\begin{array}{c}\text { Konse } \\
\text { ntrasi } \\
* \\
(\mu \mathrm{g} / \mathrm{m} \\
\mathrm{L})\end{array}$ & Area & $\begin{array}{l}\text { Area } \\
\text { rata- } \\
\text { rata }\end{array}$ & $\begin{array}{c}\mathrm{KV} \\
\text { area } \\
(\%)\end{array}$ & $\begin{array}{c}\text { Konsentr } \\
\text { asi yang } \\
\text { didapatk } \\
\text { an } \\
*(\mu \mathrm{g} / \mathrm{mL})\end{array}$ & $\mathrm{UPK}(\%)$ & $\begin{array}{l}\text { UPK } \\
\text { rata- } \\
\text { rata } \\
(\%)\end{array}$ & $\begin{array}{l}\mathrm{KV} \\
(\%)\end{array}$ \\
\hline \multirow{3}{*}{0,5193} & 52567,14 & \multirow{3}{*}{52323,3} & \multirow{3}{*}{0,46} & 0,5175 & 99,65 & \multirow{3}{*}{99,18} & \multirow{3}{*}{0,46} \\
\hline & 52083,82 & & & 0,5127 & 98,72 & & \\
\hline & 52318,94 & & & 0,5150 & 99,17 & & \\
\hline
\end{tabular}

\section{Kadar akrilamida dalam sampel}

Sampel yang dianalisa dalam penelitian ini terdiri dari 3 produk roti kering yang diperoleh dari 2 titik yang beredar di daerah Jakarta Timur. Pengambilan sampel dilakukan dengan teknik investigasi sampling, yaitu berdasarkan kriteria masa kadaluarsa dan perbedaan wilayah pemasaran produk untuk tiap sampel yang digunakan dengan berbagai merek yang berbeda. Pengambilan sampel ini diharapkan dapat mewakili dari populasi yang ada (Broto.R. 1977). Adapun hasil penetapan kadar rata-rata akrilamida yang terdapat pada masing-masing sampel adalah sebagai berikut :

Tabel 5. Hasil penetapan kadar akrilamida pada sampel roti kering

\begin{tabular}{|c|c|c|c|c|c|c|}
\hline $\begin{array}{c}\text { Sampel } \\
1\end{array}$ & Area & $\begin{array}{c}\text { Konsentrasi } \\
\text { yang } \\
\text { didapat } \\
(\mu \mathrm{g} / \mathrm{mL})\end{array}$ & $\begin{array}{l}\text { Kadar } \\
(\mu \mathrm{g} / \mathrm{g})\end{array}$ & $\begin{array}{c}\text { Kadar } \\
\text { rata- } \\
\text { rata } \\
(\mu \mathrm{g} / \mathrm{g})\end{array}$ & $\begin{array}{c}\text { RSD } \\
\text { kadar } \\
(\%)\end{array}$ & $\begin{array}{c}\text { Kadar } \\
\mathrm{A}, \mathrm{B} \\
\text { rata- } \\
\text { rata } \\
(\mu \mathrm{g} / \mathrm{g}) \pm \\
\mathrm{SD}\end{array}$ \\
\hline & 2865,01 & 0,0273 & 0,0354 & & & \multirow{4}{*}{$\begin{array}{c}0,0541 \pm \\
0,0270\end{array}$} \\
\hline $\mathrm{A}$ & 2810,83 & 0,0267 & 0,0347 & 0,0350 & 1,14 & \\
\hline \multirow[b]{2}{*}{ B } & 5833,64 & 0,0565 & 0,0734 & \multirow[b]{2}{*}{0,0732} & \multirow[b]{2}{*}{0,27} & \\
\hline & 5807,64 & 0,0563 & 0,0731 & & & \\
\hline $\begin{array}{l}\text { Sampel } \\
2\end{array}$ & Area & $\begin{array}{c}\text { Konsentrasi } \\
\text { yang } \\
\text { didapat } \\
(\mu \mathrm{g} / \mathrm{mL})\end{array}$ & $\begin{array}{l}\text { Kadar } \\
(\mu \mathrm{g} / \mathrm{g})\end{array}$ & $\begin{array}{c}\text { Kadar } \\
\text { rata- } \\
\text { rata } \\
(\mu \mathrm{g} / \mathrm{g})\end{array}$ & $\begin{array}{c}\text { RSD } \\
\text { kadar } \\
(\%)\end{array}$ & $\begin{array}{c}\text { Kadar A, } \\
\text { B rata- } \\
\text { rata } \\
(\mu \mathrm{g} / \mathrm{g}) \pm \\
\text { SD }\end{array}$ \\
\hline & 3427,99 & 0,0310 & 0,0403 & & & \multirow{4}{*}{$\begin{array}{c}0,0851 \pm \\
0,0629\end{array}$} \\
\hline & 3300,82 & 0,0316 & 0,0410 & 0,0406 & 0,98 & \\
\hline \multirow[b]{2}{*}{ B } & 10183,53 & 0,0994 & 0,1292 & \multirow[b]{2}{*}{0,1296} & \multirow[b]{2}{*}{0,38} & \\
\hline & 10242,22 & 0,1000 & 0,1300 & & & \\
\hline
\end{tabular}




\begin{tabular}{|c|c|c|c|c|c|c|}
\hline $\begin{array}{c}\text { Sampel } \\
3\end{array}$ & Area & $\begin{array}{c}\text { Konsentrasi } \\
\text { yang } \\
\text { didapat } \\
(\mu \mathrm{g} / \mathrm{mL})\end{array}$ & $\begin{array}{l}\text { Kadar } \\
(\mu \mathrm{g} / \mathrm{g})\end{array}$ & $\begin{array}{c}\text { Kadar } \\
\text { rata- } \\
\text { rata } \\
(\mu \mathrm{g} / \mathrm{g})\end{array}$ & $\begin{array}{c}\text { RSD } \\
\text { kadar } \\
(\%)\end{array}$ & $\begin{array}{c}\text { Kadar A, } \\
\text { B rata- } \\
\text { rata } \\
(\mu \mathrm{g} / \mathrm{g}) \pm \\
\text { SD }\end{array}$ \\
\hline \multirow[b]{2}{*}{ A } & 13059,06 & 0,1278 & 0,1661 & & & \multirow{4}{*}{$\begin{array}{c}0,3445 \pm \\
0,2539\end{array}$} \\
\hline & 12878,93 & 0,1260 & 0,1638 & 0,1649 & 0,97 & \\
\hline \multirow[b]{2}{*}{ B } & 41384,35 & 0,4072 & 0,5293 & \multirow[b]{2}{*}{0,5241} & \multirow[b]{2}{*}{1,37} & \\
\hline & 40584,18 & 0,3993 & 0,5190 & & & \\
\hline
\end{tabular}

Bila dibandingkan dengan kadar akrilamida pada produk pangan yang lain (Krisnasari D., 2005; Handayani. 2006; Zubaidah. 2006), akrilamida yang terdapat dalam sampel roti kering kadarnya lebih kecil, hal ini disebabkan karena pada biskuit memiliki kandungan karbohidrat tinggi yang merupakan sumber utama dari pembentukan akrilamida. Variasi kadar akrilamida yang didapat selain disebabkan oleh pengaruh suhu dan waktu pemanggangan, kemungkinan juga dipengaruhi oleh komposisi karbohidrat di dalam makanan tersebut sebagai komponen utama dalam makanan. Ambang batas yang ditetapkan oleh FDA untuk kadar akrilamida dalam makanan adalah $2 \mathrm{~g} / \mathrm{kg}$ (U.S. Food and Drug Administration (FDA). 2004.). Bila dibandingkan dengan hasil penelitian ini kadar akrilamida yang didapat cukup tinggi namun masih relatif aman untuk dikonsumsi.

Meskipun kadar akrilamida dalam roti kering masih jauh dari nilai ambang batas yang diperbolehkan, akan tetapi asupan akrilamida dalam makanan yang dikonsumsi dapat terakumulasi di dalam tubuh dan dikhawatirkan dapat berdampak negatif terhadap kesehatan manusia. Akrilamida yang terakumulasi akan memicu terjadinya proses karsinogenesis karena terbentuknya glisidamida yang merupakan suatu epoksida yang bersifat genotoksik dan penyebab terjadinya kanker. Oleh karena itu konsumsi roti kering yang berlebih tetap harus dihindari untuk mencegah terjadinya akumulasi akrilamida di dalam tubuh.

\section{KESIMPULAN \& SARAN}

Berdasarkan hasil penelitian ini, dapat disimpulkan:

1. Hasil validasi metode menunjukkan nilai koefisien linieritas (R2 ) 0,999982; batas deteksi (LOD) $0.0126 \mu \mathrm{g} / \mathrm{mL}$; batas kuantitasi (LOQ) $0.0420 \mu \mathrm{g} / \mathrm{mL}$; koefisien variasi dari fungsi (Vxo) sebesar $0.6700 \%$ $(<5 \%)$ dan nilai RSD sebesar 0,38\%,
$0,74 \%$ dan $0,21 \%$ serta nilai uji perolehan kembali sebesar $98,18 \%$ untuk konsentrasi $0,5193 \mu \mathrm{g} / \mathrm{mL}$.

2. Dari ketiga sampel produk roti kering yang dianalisa, ketiganya terbukti mengandung akrilamida dengan kadar rata-rata akrilamida yang terdapat pada sampel 1 adalah $0.0541 \pm 0.0270 \mu \mathrm{g} / \mathrm{g}$, sampel 2 adalah $0.0851 \pm 0.0629 \mu \mathrm{g} / \mathrm{g}$, dan sampel 3 adalah $0.3445 \pm 0.2539 \mu \mathrm{g} / \mathrm{g}$. Namun demikian, nilai tersebut masih relatif aman karena berada dibawah ambang batas yang ditetapkan oleh FDA $2 \mu \mathrm{g} / \mathrm{g}$ (sampel).

Dari hasil penelitian ini, disarankan untuk:

- Mengoptimasi teknik ekstraksi akrilamida pada matriks sampel yang berbeda agar diperoleh data yang lebih komprehensif dan memberikan informasi yang lebih lengkap.

- Perlu dibandingkan hasil pengujian dengan metode lainnya yang lebih sensitif dan efisien dalam penetapan kadar akrilamida, misalnya dengan menggunakan alat GCMS untuk membandingkan unjuk kerja dari alat dan metode yang dipilih.

\section{DAFTAR PUSTAKA}

1. Anonim. 1976. The Merck Index 9th Edition. Rahway NJ: Merck \& Co. Inc., 17; 2432.

2. Krisnasari Dian Pratami. 2005. Analisis Akrilamida Dalam Beberapa Sediaan Kripik Kentang (Potato Chips) Yang Beredar Dipasaran Secara KCKT. Skripsi Sarjana Farmasi FMIPA-UI: Depok.

3. Edi Yoky. 2009. Verifikasi dan Validasi Metoda di Laboratorium.

4. Handayani Fitria. 2006. Analisis Akrilamida Dalam Kopi Instant Secara KCKT. Skripsi Sarjana Farmasi FMIPA-UI:Depok.

5. Harahap Yahdiana. 2006. Pembentukan Akrilamida Dalam Makanan Dan Analisisnya. http://jurnal.farmasi.ui.ac.id/pdf/2006/v03n03/a krilamid.pdf -, kamis, 12 maret 2009, pukul 14.26

6. Harmita. 2004. Petunjuk pelaksanaan Validasi Metode dan Cara Perhitunganya. Majalah Ilmu Kefarmasian, I(3). Departemen Farmasi FMIPA-UI: Depok.

7. Hertono, Broto.R. 1977. Cara-Cara Sampling. Fakultas Kesehatan Masyarakat. Universitas Indonesia: Depok. 
8. Ibrahim Slamet. 1998. Pengembangan Metode Analisis Menggunakan Kromatografi Cair Kinerja Tinggi. Seminar on HPLC Application for Analysis of Drugs, Food and Environment. Bandung: Perpustakaan Pusat ITB.

9. Lubomir Karasek, Szilard Szilagyi, Thomas Wenzl, Proficiency Test on The Determination of Acrylamide in Potato Crisps, Final Report, European Communication, Belgium, 2008.

10. Noviandri Indra. 2004. Sampling untuk Analisis. Departemen Kimia Fakultas Matematika dan Ilmu Pengetahuan Alam ITB: Bandung.

11. Office of Environtmental Helath Hazard Assesment (OEHHA). 2005. The No Significant Risk Level (NRSL) for the Proposition 65 Carcinogen.

12. Otles S. 2004. Acrylamide in Food (Chemical Structure of Acrylamide). Electronic Journal of
Environmental, Agricultural and Food Chemistry.

13. U.S. EPA Office of Solid Waste (OSW) Methods, Team Ariel Rios Bldg. (5307W) 1200 Pennsylvania Ave. NW Washington, DC 20460, didownload dari http://www.epa.gov/epaoswer/hazwaste/test/ind ex.htm, (12 Maret 2011)

14. U.S. Food and Drug Administration (FDA). 2004. Exploratory Data on Acrylamide in Food.U.S. FDA, CFSAN/Office of Plant \& Dairy Foods.

15. WHO, 2002. Health Implication of Acrylamide in Food: Report of a Joint FAO/WHO Consultation. Geneve, Swiss: World Health Organization(WHO).

16. Zubaidah. 2006. Analisis Akrilamida Dalam Berbagai Produk Crackers Secara KCKT. Skripsi Sarjana Farmasi FMIPA-UI: Depok. 